Review

\title{
Bone loss
}

\section{Quantitative imaging techniques for assessing bone mass in rheumatoid arthritis Christopher F Njeh and Harry K Genant \\ Department of Radiology, University of California, San Francisco, California, USA}

Received: 27 January 2000

Accepted: 17 July 2000

Published: 3 August 2000
Arthritis Res 2000, 2:446-450

(c) Current Science Ltd (Print ISSN 1465-9905; Online ISSN 1465-9913)

\begin{abstract}
Osteoporosis is associated with low bone mass and microarchitectural deterioration of bone tissue with clinical manifestation of low trauma fractures. Rheumatoid arthritis (RA) is a risk factor due to generalized and articular bone loss. This minireview presents past and current bone mass measurement techniques in RA. These techniques include: plain radiographs, absorptiometry, quantitative computed tomography (QCT) and ultrasound. The most widely used technique is dual $x$-ray absorptiometry (DXA). RA patients have lower bone mass as compared with normals and substantial bone loss may occur early after the onset of disease. Measurement of bone mineral density (BMD) at the hand using either DXA or ultrasound maybe a useful tool in the management of RA patients.
\end{abstract}

Keywords: bone density, bone loss, osteoporosis, quantitative ultrasound, rheumatoid arthritis, $\mathrm{x}$-ray absorptiometry

\section{Introduction}

RA is associated with both generalized [1] and articular bone loss, which could be due to the disease itself, to inactivity or to treatment with corticosteroids [2]. Bone loss results in low bone mass and microarchitectural deterioration of bone tissue, leading to diminished biomechanical competence of the skeleton. This condition is often termed osteopenia or osteoporosis and the clinical consequence is low-trauma or atraumatic fractures, particularly at the spine, hip and wrist. The most serious fractures are those of the hip, which contribute substantially to morbidity, mortality and health care costs [3]. Although the pathophysiology of osteoporosis is multifactorial and complex, studies have shown that bone mass is the most important determinant of bone strength and accounts for up to $80 \%$ of its variance $[4,5]$. Decreased bone mass is therefore a useful predictor of increased fracture risk [6]. Many prospective studies have shown that a decrease in bone density at the spine or hip of one SD increases fracture risk by a factor of two to three [7-10]. Methods of measuring BMD are therefore pertinent to the detection of osteopenia, the identification of those individuals at risk of atraumatic fracture, and the assessment of efficacy of either prevention or treatment of associated osteoporosis.

Considerable advancement has been made in noninvasive methods for assessing bone status in the axial and peripheral skeleton in the past 25 years [11]. These

$\mathrm{BMD}=$ bone mineral density; $\mathrm{CT}=$ computed tomography; DPA = dual photon absorptiometry; $\mathrm{DXA}=$ dual $\mathrm{X}$-ray absorptiometry; $\mathrm{kV} p=$ peak kilovoltage; PA = posterior-anterior; pOCT = peripheral quantitative computed tomography; QCT = quantitative computed tomography; QUS = quantitative ultrasound; RA = rheumatoid arthritis; SPA = single photon absorptiometry; SXA = single X-ray absorptiometry. 
methods include photon and X-ray absorptiometry, QCT and quantitative ultrasound (QUS) [11-13]. The application of some of these techniques for longitudinal assessment in RA has been reviewed by Lane et al [14], Deodhar and Woolf [15] and Verhoeven and Boers [16]. The choice of site for monitoring depends on two variables: firstly, the rate of change of bone mass within the skeleton itself and, secondly, precision of bone density testing at particular sites. In general, the measured change in bone density should be 2.8 times the long-term precision error for the measured variable $[17,18]$. This review presents past and present techniques for bone mass measurement for the serial assessment of bone loss in RA.

\section{Radiographic techniques Plain radiographs}

Conventional radiographs of the peripheral joints are frequently used for the diagnosis and assessment of disease progression in RA $[19,20]$. RA can be characterized by the presence of erosions, periarticular osteoporosis, calcification and/or joint space narrowing. To evaluate these changes, many radiographic scoring systems that require a single posterior-anterior (PA) film of the hands and wrist have been developed [21]. However, these methods are imprecise and coarse for the assessment of osteoporosis. Also, juxta-articular bone loss precedes the development of erosions and this does not become apparent radiologically until a considerable proportion (more than 35\%) of the bone mineral has been lost [22].

\section{Radiographic absorptiometry}

Radiographic absorptiometry, the first quantitative technique to assess integral bone, has recently gained renewed interest as a simpler, readily available screening tool [23]. In radiographic absorptiometry, standardized hand radiographs are taken with an aluminum step-wedge placed on the film and the imaged is analyzed with an optical densitometer. The BMD is determined by comparison with the defined density of the aluminum step-wedge. The results are expressed in aluminum equivalent values or arbitrary units [24]. This is a low-cost and potentially widely available technique but is it restricted to the appendicular bones such as the metacarpals and phalanges, which are surrounded by a relatively small amount of soft tissue. Improvements in obtaining X-rays under standard conditions and recently developed computer-assisted methods have reduced operator errors and improved precision $[25,26]$. Radiographic absorptiometry seems to be suitable for measuring the BMD of the phalanges and metacarpals $[11,27]$.

\section{Absorptiometry \\ Single X-ray absorptiometry}

Single X-ray absorptiometry (SXA), with its high photon flux, has superseded single photon absorptiometry (SPA). The replacement of the photon source with an X-ray tube imparted greater precision and improved spatial resolution of these systems and reduced examination time [28]. The method overcomes the problems of radiographic absorptiometry caused by non-uniformity of film sensitivity and processing. To correct for overlying soft tissue, the anatomic site at which BMD is being measured has to be surrounded by either a constant thickness of water, water bags or water-equivalent moldable materials [13]. SXA makes possible a quantitative assessment of bone mineral content only at peripheral sites of the skeleton. At the radius, BMD measurements are performed at the ultradistal, distal and shaft regions. The precision of $1-2 \%$ depends on the site, with better precision at the shaft region. The calcaneus is also a site of interest because it is load bearing and has a high cancellous bone content $[29,30]$. SXA has proved to be a valuable method in the diagnosis of osteoporosis, providing reasonable precision and low exposure to radiation.

\section{Dual X-ray absorptiometry}

DXA was introduced commercially in 1987 as the direct successor to dual photon absorptiometry (DPA) [31]. The fundamental physical principle behind DXA is the simultaneous measurement of $\mathrm{X}$-rays with two different energies through the body. The dual X-ray spectrum can be generated using either K-edge filters or peak kilovoltage $(\mathrm{kVp})$ switching [32]. The main advantages of an X-ray system over a DPA radionuclide system are the following: a shortened examination time because the $\mathrm{X}$-ray source produces a much higher photon fluence, greater accuracy and precision, and the removal of errors due to corrections for source decay $[33,34]$. A more recent development in DXA technology has been the introduction of a new generation of fan beam scanners such as the Hologic QDR 4500 (Hologic Inc., Bedford, Massachusetts, USA) and the Lunar Expert-XL and the Lunar Prodigy (Lunar Corp., Madison, Wisconsin, USA). Fan beam scanners perform one or more sweeps across the patient instead of the two-dimensional raster scan required by pencil beam geometry. As a result, scan times have been shortened from 5-10 min to $10-30 \mathrm{~s}$, with a consequent higher patient throughput. Another advantage of the fan beam system is the higher image resolution $[35,36]$. This permits the easier identification of vertebral structures and artefacts caused by degenerative disease.

The preferred anatomic sites for DXA measurement of bone mineral include the lumbar spine (L1-L4), the proximal femur (neck, trochanter, Ward's triangle and total hip) and the whole body, but peripheral sites can also be measured. DXA has been used in numerous studies involving RA subjects [1,37-40]. Van Schaardenburg et al [40] reported significant corticosteroid-induced spinal and femoral bone loss in patients with RA in a randomized, placebo-controlled trial on the effects of steroid treatment on bone mass. Disease duration seems to be an important determinant of bone loss 
in RA. Two longitudinal studies with DXA showed that patients with RA lose BMD in the lumbar spine and femur mainly in the early part of their disease $[1,38]$. Gough et al [1] also showed that patients with early RA, treated with $1-5 \mathrm{mg}$ of prednisone daily, lost more bone than patients taking daily doses of more than $5 \mathrm{mg}$.

Recently, peripheral DXA (pDXA) densitometers especially designed for forearm or calcaneal measurements have been introduced and might provide these measurements at a lower cost $[11,41]$. For application in RA, hand BMD has been studied with some interest because it is the principal site of inflammation and is of prime functional importance $[39,42-44]$. Earlier studies did not have dedicated software to measure hand $B M D$ and thus adapted spine software for Holigic DXA scanners $[39,42]$ or small-animal software for Lunar DXA scanners [43]. Hand BMD measurement with DXA proved highly accurate and reproducible. Hand BMD was also significantly correlated with BMD at other sites. In a prospective longitudinal study of hand BMD in patients with RA, Deodhar et al [45] showed that, despite significant improvement in clinical and laboratory indices of disease activity, there was a significant loss of hand BMC during 1 year (5.26\% in males, $2.14 \%$ in females).

\section{Quantitative computed tomography}

QCT can be performed on clinical computed tomography (CT) scanners to determine in three dimensions the true volumetric density $\left(\mathrm{mg} / \mathrm{cm}^{3}\right)$ of cancellous or cortical bone. However, because of the high responsiveness of vertebral cancellous bone, and its importance in vertebral strength, QCT has been employed principally to determine cancellous bone density in the vertebral body [46]. A spinal QCT examination requires that an external bone mineral reference phantom be scanned together with the patient to calibrate the CT number measurements to bone-equivalent values. QCT's ability to selectively assess the metabolically active and structurally important trabecular bone in the vertebral body results in an excellent ability to discriminate vertebral fracture and to measure bone loss, generally with better sensitivity than projectional methods such as DXA $[46,47]$. The average cross-sectional bone-loss rate in females from young to old is typically $1.2 \%$ per year when measured with QCT and a little over half that value when measured with DXA. However, compared with DXA, QCT scanners are much more expensive, the precision of BMD measurement is poorer and the radiation dose to the patient, although acceptable, is much higher.

To some extent, the high cost of and limited access to conventional all-purpose CT scanners has prompted the development of dedicated peripheral QCT (pQCT) instrumentation specifically for measurements of purely trabecular and cortical BMC and BMD in the radius $[48,49]$. pQCT delivers a lower dose of radiation to the patient than standard spinal QCT because only the appendicular skeleton is irradiated. Unlike SPA or SXA, pQCT uses a transaxial image to allow separate measurement of the true volumetric density $\left(\mathrm{mg} / \mathrm{cm}^{3}\right)$ and cross-sectional area of trabecular and cortical bone without superposition of other tissues, and provides exact three-dimensional localization of the target volume. The ability to measure the metabolically more active trabecular bone and determine geometric parameters related to the cortical shell such as moment of inertia and mean thickness, as well as the ease of use, make pQCT an interesting alternative to SPA or SXA $[11,50]$. QCT has been used to study bone loss in RA subjects [51-53] in whom significant loss was observed in trabecular bone compared with cortical bone.

\section{Ultrasound}

QUS has been established as another modality in the assessment of skeletal status. The advantages of QUS include the fact that the equipment is inexpensive, small and portable, and does not involve the use of ionizing radiation. Moreover, indirect studies and/or studies in vitro have suggested that ultrasound might give information not only about bone density but also about architecture and elasticity [12,54-57]. These benefits, combined with clinical results showing good diagnostic sensitivity for fracture discrimination, have encouraged further basic investigation and commercial development. Several manufacturers have developed different QUS systems since the late 1980s. Most of the commercial QUS systems measure the calcaneus submerged in a water bath or with ultrasonic gel as couplant and a fixed single-point transmission transducer system. Recent developments include calcaneal transmission imaging, phalangeal, tibial and multisite measuring devices [58].

Bone tissue can be characterized in terms of speed of sound (SOS) and broadband ultrasound attenuation (BUA). These parameters are significantly positively correlated with BMD in vivo. Site-matched comparisons of BMD and QUS measurements have produced correlations of approx. 0.7-0.90 [12]. Both cross-sectional and prospective studies have demonstrated that QUS can be used to discriminate normal from osteoporotic subjects nearly as effectively as traditional bone densitometry approaches [55,59-61]. The ability of QUS to discriminate between normal and osteoporotic patients is partly independent of BMD in some cases [60]. There is a growing interest in the use of phalangeal ultrasound [62] and calcaneal ultrasound [63-66] to assess bone status in RA patients. Martin et al [64] demonstrated a significant decrease in both ultrasound attenuation (31.7\%) and velocity $(6.6 \%)$ measured at the calcaneus of RA patients in comparison with controls. In studies by Daens et al [65] and Blanckaert et al [66], QUS performed similarly to BMD measured at the spine and femur in evaluating glucocorticoid-induced osteoporosis. 


\section{Conclusion}

The most prevalent methods for assessing the skeleton are SXA, DXA, QCT and QUS; these have been applied successfully in the measurement of bone loss in RA.

Patients with RA have lower bone mass in the appendicular and axial skeleton than normals.

Longitudinal densitometry studies demonstrate that substantial loss of bone mass can occur early in the first year after the onset of disease.

The hand is an area of considerable disease activity; therefore measurement of BMD at the hand with either DXA or ultrasound may be a useful tool in the management of RA patients.

\section{References}

1. Gough AK, Lilley J, Eyre S, Holder RL, Emery P: Generalised bone loss in patients with early rheumatoid arthritis. Lancet 1994, 344: 23-27.

2. Celiker R, Gokce-Kutsal Y, Cindas A, Ariyurek M, Renda N, Koray Z, Basgoze O: Osteoporosis in rheumatoid arthritis: effect of disease activity. Clin Rheumatol 1995, 14:429-433.

3. Cooper C, Atkinson EJ, Jacobsen SJ, O'Fallon WM, Melton LJd. Population-based study of survival after osteoporotic fractures. $\mathrm{Am} J$ Epidemiol 1993, 137:1001-1005.

4. Hodgskinson R, Njeh CF, Currey JD, Langton CM: The ability of ultrasound velocity to predict the stiffness of cancellous bone in vitro. Bone 1997, 21:183-190.

5. Rice JC, Cowin SC, Bowman JA: On the dependence of the elasticity and strength of cancellous bone on apparent density. J Biomech 1988, 21:155-168.

6. Ross PD, Davis JW, Vogel JM, Wasnich RD: A critical review of bone mass and the risk of fractures in osteoporosis. Calcif Tissue Int 1990, 46:149-161.

7. Cummings SR, Black DM, Nevitt MC, Browner W, Cauley J, Ensrud K, Genant HK, Palermo L, Scott J, Vogt TM: Bone density at various sites for prediction of hip fractures. The Study of Osteoporotic Fractures Research Group. Lancet 1993, 341:72-75.

8. Marshall $D$, Johnell $O$, Wedel H: Meta-analysis of how well measures of bone mineral density predict occurrence of osteoporotic fractures. Br Med J (Clin Res Ed) 1996, 312:1254-1259.

9. Nevitt MC, Johnell O, Black DM, Ensrud K, Genant HK, Cummings SR: Bone mineral density predicts non-spine fractures in very elderly women. Study of Osteoporotic Fractures Research Group. Osteoporos Int 1994, 4:325-331.

10. Nguyen T, Sambrook P, Kelly P, Jones G, Lord S, Freund J, Eisman J: Prediction of osteoporotic fractures by postural instability and bone density. Br Med J 1993, 307:1111-1115.

11. Genant HK, Engelke K, Fuerst T, Gluer CC, Grampp S, Harris ST, Jergas M, Lang T, Lu Y, Majumdar S, Mathur A, Takada M: Noninvasive assessment of bone mineral and structure: state of the art. J Bone Miner Res 1996, 11:707-730.

12. Njeh CF, Boivin CM, Langton CM: The role of ultrasound in the assessment of osteoporosis: a review. Osteoporos Int 1997, 7: 7-22.

13. Adams JE: Single and dual energy X-ray absorptiometry. Eur Radiol 1997, 7 (Suppl 2):S20-S31.

14. Lane NE, Jergas M, Genant HK: Osteoporosis and bone mineral assessment. In Arthritis and Allied Condition. a Textbook of Rheumatology. Edited by Koopman WJ. Baltimore: Williams \& Wilkins; 1997:153-174.

15. Deodhar AA, Woolf AD: Bone mass measurement and bone metabolism in rheumatoid arthritis: a review. $\mathrm{Br} J$ Rheumato/ 1996, 35:309-322.

16. Verhoeven AC, Boers M: Limited bone loss due to corticosteroids: a systematic review of prospective studies in rheumatoid arthritis and other diseases. J Rheumatol 1997, 24:1495-1503.
17. Blake GM, Jagathesan T, Herd RJ, Fogelman I: Dual X-ray absorptiometry of the lumbar spine: the precision of paired anteroposterior/lateral studies. $\mathrm{Br} J$ Radiol 1994, 67:624-630.

18. Hassager C, Jensen SB, Gotfredsen A, Christiansen C: The impact of measurement errors on the diagnostic value of bone mass measurements: theoretical considerations. Osteoporos Int 1991, 1: 250-256.

19. van der Heijde DM: Plain X-rays in rheumatoid arthritis: overview of scoring methods, their reliability and applicability. Baillieres Clin Rheumatol 1996, 10:435-453.

20. Scott DL, Coulton BL, Bacon PA, Popert AJ: Methods of X-ray assessment in rheumatoid arthritis: a re-evaluation. $\mathrm{Br} J$ Rheumatol 1985, 24:31-39.

21. Kaye JJ: Radiographic assessment of rheumatoid arthritis. Rheum Dis Clin North Am 1995, 21:395-406.

22. Jergas M, Uffmann M, Escher H, Glüer CC, Young KC, Grampp S, Köster $\mathrm{O}$, Genant HK: Interobserver variation in the detection of osteopenia by radiography and comparison with dual $\mathbf{x}$-ray absorptiometry (DXA) of the lumbar spine. Skeletal Radiol 1994, 23:195-199.

23. Morgan DB, Spiers FW, Pulvertaft CN, Fourman P: The amount of bone in the metacarpal and phalanx according to age and sex. Clin Radiol 1967, 18:101-108.

24. Yang SO, Hagiwara S, Engelke K, Dhillon MS, Guglielmi G, Bendavid EJ, Soejima O, Nelson DL, Genant HK: Radiographic absorptiometry for bone mineral measurement of the phalanges: precision and accuracy study. Radiology 1994, 192:857-859.

25. Matsumoto C, Kushida K, Yamazaki K, Imose K, Inoue T: Metacarpal bone mass in normal and osteoporotic Japanese women using computed x-ray densitometry. Calcif Tissue Int 1994, 54:324-329.

26. Kalebo $P$, Strid $K G$ : Bone mass determination from microradiographs by computer-assisted videodensitometry. II: Aluminium as a reference substance. Acta Radiol 1988, 29:611-617.

27. Yates AJ, Ross PD, Lydick E, Epstein RS: Radiographic absorptiometry in the diagnosis of osteoporosis. Am J Med 1995, 98:41S-47S.

28. Kelly TL, Crane G, Baran DT: Single X-ray absorptiometry of the forearm: precision, correlation, and reference data. Calcif Tissue Int 1994, 54:212-218.

29. Vogel JM, Wasnich RD, Ross PD: The clinical relevance of calcaneus bone mineral measurements: a review. Bone Miner 1988, 5: 35-58.

30. Suominen $H$, Heikkinen $E$, Vainio $P$, Lahtinen $T$ : Mineral density of calcaneus in men at different ages: a population study with special reference to life-style factors. Age Ageing 1984, 13:273281.

31. Sim LH, van Doorn T: Radiographic measurement of bone mineral: reviewing dual energy X-ray absorptiometry. Australas Phys Eng Sci Med 1995, 18:65-80.

32. Blake GM, Wahner HW, Fogelman I: The Evaluation of Osteoporosis: Dual Energy $X$-ray Absorptiometry and Ultrasound in Clinical Practice, edn 2. London: Martin Dunitz; 1999.

33. Kelly T, Slovick D, Schoenfield D, Neer R: Quantitative digital radiography versus dual photon absorptiometry of the lumbar spine. $J$ Clin Endocr Metab 1988, 67:839-844.

34. Mazess R, Chesnut CHd, McClung M, Genant H: Enhanced precision with dual-energy X-ray absorptiometry. Calcif Tissue Int 1992, 51:14-17.

35. Blake GM, Parker JC, Buxton FM, Fogelman I: Dual X-ray absorptiometry: a comparison between fan beam and pencil beam scans. Br J Radiol 1993, 66:902-906.

36. Eiken $\mathrm{P}$, Kolthoff $\mathrm{N}$, Barenholdt $\mathrm{O}$, Hermansen $F$, Pors Nielsen S: Switching from DXA pencil-beam to fan-beam. II: Studies in vivo. Bone 1994, 15:671-676.

37. Shenstone BD, Mahmoud A, Woodward R, Elvins D, Palmer R, Ring F, Bhalla AK: Bone mineral density in nonsteroid treated early rheumatoid arthritis. Ann Rheum Dis 1994, 53:681-684.

38. Shenstone BD, Mahmoud A, Woodward R, Elvins D, Palmer R, Ring $\mathrm{EF}$, Bhalla AK: Longitudinal bone mineral density changes in early rheumatoid arthritis. $\mathrm{Br} J$ Rheumatol 1994, 33:541-545.

39. Peel NF, Spittlehouse AJ, Bax DE, Eastell R: Bone mineral density of the hand in rheumatoid arthritis. Arthritis Rheum 1994, 37:983991.

40. van Schaardenburg D, Valkema R, Dijkmans BA, Papapoulos S, Zwinderman $\mathrm{AH}$, Han KH, Pauwels EK, Breedveld FC: Prednisone treatment of elderly-onset rheumatoid arthritis. Disease activity and bone mass in comparison with chloroquine treatment. Arthritis Rheum 1995, 38:334-342. 
41. Mole PA, McMurdo ME, Paterson CR: Evaluation of peripheral dual energy X-ray absorptiometry: comparison with single photon absorptiometry of the forearm and dual energy X-ray absorptiometry of the spine or femur. Br J Radiol 1998, 71:427-432.

42. Deodhar AA, Brabyn J, Jones PW, Davis MJ, Woolf AD: Measurement of hand bone mineral content by dual energy $x$-ray absorptiometry: development of the method, and its application in normal volunteers and in patients with rheumatoid arthritis. Ann Rheum Dis 1994, 53:685-690.

43. Devlin J, Lilley J, Gough A, Huissoon A, Holder R, Reece R, Perkins P, Emery $\mathrm{P}$ : Clinical associations of dual-energy $\mathrm{X}$-ray absorptiometry measurement of hand bone mass in rheumatoid arthritis. $\mathrm{Br} J$ Rheumatol 1996, 35:1256-1262.

44. Ozgocmen S, Karaoglan B, Kocakoc E, Ardicoglu O, Yorgancioglu ZR: Correlation of hand bone mineral density with the metacarpal cortical index and carpo:metacarpal ratio in patients with rheumatoid arthritis. Yonsei Med J 1999, 40:478-482.

45. Deodhar AA, Brabyn J, Jones PW, Davis MJ, Woolf AD: Longitudinal study of hand bone densitometry in rheumatoid arthritis. Arthritis Rheum 1995, 38:1204-1210.

46. Genant HK, Cann CE, Ettinger B, Gordan GS: Quantitative computed tomography of vertebral spongiosa: A sensitive method for detecting early bone loss after oophorectomy. Ann Int Med 1982, 97:699-705.

47. Guglielmi G, Grimston SK, Fischer KC, Pacifici R: Osteoporosis: Diagnosis with lateral and posteroanterior dual X-ray absorptiometry compared with quantitative CT. Radiology 1994, 194:845-850.

48. Grampp S, Lang P, Jergas M, Gluer CC, Mathur A, Engelke K, Genant HK: Assessment of the skeletal status by peripheral quantitative computed tomography of the forearm: short-term precision in vivo and comparison to dual X-ray absorptiometry. J Bone Miner Res 1995, 10:1566-1576.

49. Takada M, Engelke K, Hagiwara S, Grampp S, Genant HK: Accuracy and precision study in vitro for peripheral quantitative computed tomography. Osteoporos Int 1996, 6:207-212.

50. Gluer CC, Jergas M, Hans D: Peripheral measurement techniques for the assessment of osteoporosis. Semin Nucl Med 1997, 27: 229-247.

51. Laan RF, Buijs WC, van Erning LJ, Lemmens JA, Corstens FH, Ruijs $\mathrm{SH}$, van de Putte LB, van Riel PL: Differential effects of glucocorticoids on cortical appendicular and cortical vertebral bone mineral content. Calcif Tissue Int 1993, 52:5-9.

52. Laan RF, van Riel PL, van Erning $L$, Lemmens JA, Ruijs SH, van de Putte LB: Vertebral osteoporosis in rheumatoid arthritis patients: effect of low dose prednisone therapy. $\mathrm{Br} J$ Rheumatol 1992, 31: 91-96.

53. Laan RF, van Riel PL, van de Putte LB, van Erning $L$, van't Hof MA Lemmens JA: Low-dose prednisone induces rapid reversible axial bone loss in patients with rheumatoid arthritis. A randomized, controlled study. Ann Intern Med 1993, 119:963-968.

54. Hans D, Schott AM, Meunier PJ: Ultrasonic assessment of bone: a review. Eur J Med 1993, 2:157-163.

55. Gregg EW, Kriska AM, Salamone LM, Roberts MM, Anderson SJ, Ferrell RE, Kuller LH, Cauley JA: The epidemiology of quantitative ultrasound: a review of the relationships with bone mass, osteoporosis and fracture risk. Osteoporos Int 1997, 7:89-99.

56. Cheng S, Tylavsky F, Carbone L: Utility of ultrasound to assess risk of fracture. J Am Geriatr Soc 1997, 45:1382-1394.

57. Hans D, Njeh CF, Genant HK, Meunier PJ: Quantitative ultrasound in bone status assessment. Rev Rhum Engl Ed 1998, 65:489-498.

58. Hans D, Srivastav SK, Singal C, Barkmann R, Njeh CF, Kantorovich E Gluer CC, Genant HK: Does combining the results from multiple bone sites measured by a new quantitative ultrasound device improve discrimination of hip fracture? J Bone Min Res 1999, 14:644-651.

59. Bauer DC, Gluer CC, Cauley JA, Vogt TM, Ensrud KE, Genant HK, Black DM: Broadband ultrasound attenuation predicts fractures strongly and independently of densitometry in older women. A prospective study. Study of Osteoporotic Fractures Research Group. Arch Intern Med 1997, 157:629-634.

60. Hans D, Dargent-Molina P, Schott AM, Sebert JL, Cormier C, Kotzki PO, Delmas PD, Pouilles JM, Breart G, Meunier PJ: Ultrasonographic heel measurements to predict hip fracture in elderly women: the EPIDOS prospective study. Lancet 1996, 348:511-514.

61. Pluijm SMF, Graafmans WC, Bouter LM, Lips P: Ultrasound measurements for the prediction of osteoporotic fractures in elderly people. Osteoporos Int 1999, 9:550-556.
62. Njeh CF, Boivin CM, Gardner-Medwin JM, Shaw NJ, Southwood TR: The use of finger ultrasound velocity to monitor bone status in juvenile chronic arthritis: a pilot study [abstract]. Osteoporos Int 1997, 7:300.

63. Madsen OR, Egsmose C, Hansen B, Sorensen OH: Soft tissue composition, quadriceps strength, bone quality and bone mass in rheumatoid arthritis. Clin Exp Rheumatol 1998, 16:27-32.

64. Martin JC, Munro R, Campbell MK, Reid DM: Effects of disease and corticosteroids on appendicular bone mass in postmenopausal women with rheumatoid arthritis: comparison with axial measurements. Br J Rheumatol 1997, 36:43-49.

65. Daens S, Peretz A, de Maertelaer V, Moris M, Bergmann P: Efficiency of quantitative ultrasound measurements as compared with dualenergy X-ray absorptiometry in the assessment of corticosteroidinduced bone impairment. Osteoporos Int 1999, 10:278-283.

66. Blanckaert F, Cortet B, Coquerelle P, Flipo RM, Duquesnoy B, Marchandise X, Delcambre B: Contribution of calcaneal ultrasonic assessment to the evaluation of postmenopausal and glucocorticoid-induced osteoporosis. Rev Rhumat Engl Ed 1997, 64:305313.

Authors' affiliation: Department of Radiology, University of California, San Francisco, California, USA

Correspondence: C Njeh, PhD, Osteoporosis and Arthritis Research Group, Department of Radiology, University of California,

San Francisco, 350 Parnassus Avenue, Suite 607, Box 1349,

San Francisco, CA 94143, USA. Tel: +1 415476 9805;

fax: +1 415502 8273; e-mail: christopher.njeh@oarg.ucsf.edu 